\title{
Care Services within the Elderly Support System from the Perspective of the Polish Red Cross
}

\author{
Dorota Rynkowska ${ }^{1}$
}

\begin{abstract}
Society ageing, which results in many changes both within the social and cultural spheres, is a multiaspect demographic process. Its basic determinants are mortality and reproduction rates, which are affected by social, economic, engineering and civilisation changes. The changes are related, among other things, with ageing of the population with chronic and geriatric diseases (Błędowski 2002). The natural consequence of ageing and the co-existing chronic diseases include the growing dependence and demand for care services among the seniors. As a result the population structure changes, care services are still at their development stage and the demand for the services has been increasing. The role of local-government and non-government entities in the area of support, aid and care services for the elderly has been gradually growing. The purpose of the article is to present the forms and scope of the care services for the seniors from the perspective of the Polish Red Cross support activities.
\end{abstract}

Keywords: seniors, care, support, care services, Polish Red Cross

\section{Introduction}

The progressing process of society ageing implies many changes, which may be considered at various levels, among others within the demographic, social and economic dimensions. The demographic changes and the accompanying problems with ensuring proper care to the elderly have become and will be a challenge for a majority of countries and societies (Szatur-Jaworska 2000; Synak 2002; Szatur-Jaworska, Błędowski, Dzieggielewska 2006). Currently, both within the Polish society and in the developed countries, the extension of the first stage of ageing has been observed, owing to the increasing average life expectancy. The process of demographic ageing has covered most of the European societies, including the Polish one. In accordance with the Eurostat data, the demographic age dependency ratio in the EU will reach in 2030: 38.04 for 27 countries and 35.98 for Poland, which places our country on the 14th place in the report. Just to compare, demographically older will be Germany - 46.23, Italy - 42.45 and Slovenia, whereas the youngest will be Ireland - 24.63 and Cyprus - 27 (Mielczarek 2010:12).

The demographic forecasts assume that by the year 2030 the number of people at retirement age will grow to 9 million in Poland. The process of the Polish society ageing is expected to accelerate in the years 2010-2020, which will contribute nearly 2 additional million people at retirement age (post-war baby boom). The process is going to reflect the characteristics of double ageing, i.e. the number of the oldest citizens (over 80 years) will grow from the current 0.8 million to 1.8 million in 2030 (Auleytner, Głębicka 2000). It appears from the demographic forecasts that the population ageing process will progress the fastest in the Southern and Eastern European countries, which are 
comparatively the less well-off regions of Europe. This may result in excessive differences in the socio-economic situation of the particular countries and lead to social discontent and conflicts. The whole world has been ageing but Europe the fastest, where the generally called daddy boom phenomenon combines with the decreasing number of people. The considerations of the reasons and consequences of human ageing have led to developing many theories attempting to explain the essence of the process, including R.J. Havighurst's activeness theory, E. Erikson's psycho-social personality development theory, or P.B. Balets' agreeable ageing model. All of the concepts agree that old age is an established image of human existence, combined with the health condition, personal traits and activeness in life.

The WHO distinguishes four stages of ageing: pre-elderly (between 45 and 59 years of age), young-old (60-74), middle-old (75-89), and oldest-old (90 and over).

A huge growth of the percentage of people above 80 years of age within the society structure results in the necessity of providing support to those people and their families. Additionally, owing to the illnesses characteristic to that group and the occurrence of concomitant diseases, new health care needs originate. There is also a necessity to provide the oldest old with access to care services which cannot be provided by the closest family or home assistants (Rynkowska, Błaszczuk 2016).

The fact that population ageing may be a major demographic, social and economic problem is confirmed by the example of many European countries which have undertaken a series of actions to direct their social policy such as to guarantee the elderly the proper social and medical care. A major element of the international social policy for the benefit of the seniors is to focus on institutional aid activities and support programmes. The rights of the elderly to institutional care and the duties of the care institutions in satisfying the needs of the seniors are specified in the European Social Charter (Articles 12, 13, 14, 15).

\section{Area under Study}

The object of this analysis is the form and scope of services provided in 2018 by the Polish Red Cross, Lublin Division, to help the elderly. The Polish Red Cross (PCK) is the oldest Polish humanitarian organisation established on 18 January 1919. It is an NGO being the member of the International Red Cross and Red Crescent Movement.It deals with providing humanitarian aid during disasters and wars, social care, teaching how to provide first aid, securing mass events with regard to medical services, propagating the idea of volunteer blood donation, propagation of knowledge on the international rights regarding armed conflicts. The objective of the PCK is to prevent human suffering and alleviation of suffering in any circumstances and at any time, applying objective principles without any discrimination, particularly with regard to nationality, ethnic groups, social background, race, religion, language or political beliefs. Many care tasks have been growingly performed by NGOs, such as the Polish Red Cross and its regional divisions.

Over 200,000 people have been availing of the social care provided by the PCK, which is a valuable supplementation of the caring role of the Polish state, resulting from the Act on Social Care. 
Generally, in the Lubelskie Province as many as 3,327 people declared Polish Red Cross membership in 2018.

\section{Methodology}

The main objective of the presented research is to reflect the forms and scope of the care services provided to the seniors by the PCK, Lublin Division. From among the broadly determined support domain of the PCK, the article refers to a narrow aspect of care services provided by the PCK, with the use of the method of analysing official documents in the form of reports by the PCK, Lublin Division, for the year 2018. The report on the operation of PCK Regional Division is prepared, by law and in accordance with the organisation's articles of association, by the Management Boards of each of the 16 PCK Divisions in Poland and forwarded to the Main Management Board of the PCK. The annual reports cover the financial, organisational and statutory issues, as well as employment, human resources, administrative and economic issues, and the analysis of programme activities referring to the following matters: activeness in the environment of children and youths, PCK care and educational outlets, health promotion, support to the seniors, care services and specialised care services, social support, first aid, voluntary blood donation, preparation for the event of disasters and catastrophes, promotional activities and international cooperation.

\section{Results}

The essence of the analysed problem referred to identification of the need for care services and the catalogue of the PCK offer in that regard.

In 2018, the Lublin Division of the Polish Red Cross provided social support to the total of 3,625 people, out of which 30\% were seniors, for the total amount of PLN 340,000. The all-year forms of support by the Polish Red Cross include: providing extra meals, ad-hoc support, night shelters, support to the foreigners, care of the ill at their homes in the form of care services or specialised care services.

Among the programme tasks of the PCK, a distinctive place is occupied by the care services provided at the homes of the ill. The Polish Red Cross has observed a gradual increase in the number of orders filed for care services and specialised care services, both in the form of recommended actions, and obtained from private individuals. Compared to the previous years, the number of care service and specialised care service hours at the homes of the ill ordered with the PCK has been significantly increasing. Therefore, the number of hours worked by the PCK carers grew by 203,735 compared to 2017.

The care services and specialised care services provided at the homes by the Lublin Division of the Polish Red Cross (to the orders of city and municipal governments based on the competition and tender formula) were carried out by 613 carers to 1,814 beneficiaries. 
Table 1. Care services ordered by external entities

\begin{tabular}{|c|c|c|c|c|c|c|}
\hline \multirow[t]{2}{*}{$\begin{array}{l}\text { PCK } \\
\text { Division }\end{array}$} & \multirow[t]{2}{*}{$\begin{array}{l}\text { Number of } \\
\text { beneficiaries }\end{array}$} & \multirow[t]{2}{*}{$\begin{array}{c}\text { Average } \\
\text { number of } \\
\text { PCK nurses }\end{array}$} & \multicolumn{2}{|c|}{$\begin{array}{l}\text { Number of service hours } \\
\text { provided to the order of } \\
\text { welfare centres }\end{array}$} & \multicolumn{2}{|c|}{$\begin{array}{c}\text { Number of service } \\
\text { hours provided within } \\
\text { the business operations }\end{array}$} \\
\hline & & & 2016 & 2017 & 2016 & 2017 \\
\hline Biłgoraj & 64 & 23 & $33,095.0$ & $44,923.0$ & $1,945.0$ & 740.0 \\
\hline Hrubieszów & 96 & 16 & $37,957.0$ & $31,942.0$ & 917.0 & 771.0 \\
\hline Kraśnik & 159 & 69 & $86,979.0$ & $83,201.0$ & --- & 166.0 \\
\hline Lubartów & 85 & 32 & $29,421.0$ & $41,152.0$ & --- & --- \\
\hline Lublin & 821 & 321 & $377,335.5$ & $344,223.0$ & $9,898.5$ & $3,895.0$ \\
\hline Puławy & 273 & 88 & $148,898.5$ & $138,638.5$ & $11,474.0$ & $9,572.5$ \\
\hline $\begin{array}{l}\text { Tomaszów } \\
\text { Lubelski }\end{array}$ & 1 & 1 & --- & --- & $1,724.0$ & 141.0 \\
\hline Zamość & 315 & 63 & $110,983.0$ & $114,897.0$ & $6,600.5$ & $3,934.0$ \\
\hline Total & 1,814 & 613 & $824,669.0$ & $798,976.5$ & $32,559.0$ & $19,219.5$ \\
\hline
\end{tabular}

In 2018, the number of care outlets was maintained at the level of 2017. The PCK nurses providing care to the ill at their homes fulfil the tasks belonging to the care and specialised care service categories. In that regard, they are graduates of profiled training in that regard or post-secondary speciality schools. The training for new and existing carers is provided periodically by the PCK Regional Divisions.

The persons providing care services are employed based on civil-law agreements, with social security contributions paid. The analysis of the presented data (Tab. 1) reflects that the basic scope of duties related to care services comprises mainly the activities of household care, cleaning, shopping, and further nursing, medicines administration, as well as preparing and serving meals. Apart from the typical nursing tasks and medicines administration, which is carried out by most of the carers, typical household chores are performed (cleaning, shopping). Moreover, the carers help in the social functioning of their charges, or even provide psychological support to the families of the charges. Some of the respondents perform typically medical tasks, as insulin administration, massage, or rehabilitation procedures.

Table 2. Activities performed by PCK carers

\begin{tabular}{|l|c|c|c|c|c|c|c|}
\hline \multirow{2}{*}{ Name of activity } & \multicolumn{7}{|c|}{ Frequency of activity } \\
\cline { 2 - 8 } & $\begin{array}{c}\text { very } \\
\text { frequently }\end{array}$ & $\begin{array}{c}\text { rather } \\
\text { frequently }\end{array}$ & $\begin{array}{c}\text { rather } \\
\text { rarely }\end{array}$ & $\begin{array}{c}\text { very } \\
\text { rarely }\end{array}$ & never & $\begin{array}{c}\text { hard } \\
\text { to say }\end{array}$ & $\begin{array}{c}\text { no } \\
\text { reply }\end{array}$ \\
\hline Cleaning & $64.55 \%$ & $20.59 \%$ & $3.37 \%$ & $0.79 \%$ & $0.88 \%$ & - & $9.90 \%$ \\
\hline Shopping & $63.37 \%$ & $16.04 \%$ & $5.94 \%$ & $2.18 \%$ & $1.19 \%$ & $0.40 \%$ & $10.89 \%$ \\
\hline $\begin{array}{l}\text { Medicines administration, } \\
\text { applying ointments, } \\
\text { compresses, etc. }\end{array}$ & $58.61 \%$ & $13.07 \%$ & $6.53 \%$ & $1.39 \%$ & $2.77 \%$ & $0.20 \%$ & $17.43 \%$ \\
\hline Making the bed & $54.26 \%$ & $18.02 \%$ & $5.74 \%$ & $2.57 \%$ & $1.178 \%$ & - & $17.62 \%$ \\
\hline Morning toilet & $53.27 \%$ & $13.86 \%$ & $5.15 \%$ & $2.97 \%$ & $3.17 \%$ & $0.40 \%$ & $21.19 \%$ \\
\hline $\begin{array}{l}\text { Preparing meals according } \\
\text { to diet }\end{array}$ & $44.95 \%$ & $16.44 \%$ & $7.13 \%$ & $3.96 \%$ & $5.94 \%$ & $0.59 \%$ & $20.99 \%$ \\
\hline Clothes changing & $44.95 \%$ & $14.85 \%$ & $8.91 \%$ & $1.98 \%$ & $3.17 \%$ & $0.20 \%$ & $25.94 \%$ \\
\hline
\end{tabular}




\begin{tabular}{|l|c|c|c|c|c|c|c|}
\hline \multirow{2}{*}{ Name of activity } & \multicolumn{7}{|c|}{ Frequency of activity } \\
\cline { 2 - 7 } & $\begin{array}{c}\text { very } \\
\text { frequently }\end{array}$ & $\begin{array}{c}\text { rather } \\
\text { frequently }\end{array}$ & $\begin{array}{c}\text { rather } \\
\text { rarely }\end{array}$ & $\begin{array}{c}\text { very } \\
\text { rarely }\end{array}$ & never & $\begin{array}{c}\text { hard } \\
\text { to say }\end{array}$ & $\begin{array}{c}\text { no } \\
\text { reply }\end{array}$ \\
\hline $\begin{array}{l}\text { Buying the prescribed } \\
\text { medicines }\end{array}$ & $43.37 \%$ & $21.19 \%$ & $9.50 \%$ & $2.97 \%$ & $2.77 \%$ & $0.59 \%$ & $19.60 \%$ \\
\hline $\begin{array}{l}\text { Incontinence pads } \\
\text { changing }\end{array}$ & $39.21 \%$ & $8.71 \%$ & $6.14 \%$ & $5.15 \%$ & $8.12 \%$ & - & $32.67 \%$ \\
\hline $\begin{array}{l}\text { Help in walking around the } \\
\text { house }\end{array}$ & $38.42 \%$ & $17.43 \%$ & $9.70 \%$ & $3.96 \%$ & $4.55 \%$ & $0.40 \%$ & $25.54 \%$ \\
\hline Bathing & $36.63 \%$ & $22.38 \%$ & $9.50 \%$ & $3.17 \%$ & $3.96 \%$ & $0.40 \%$ & $23.96 \%$ \\
\hline Walks & $34.26 \%$ & $17.03 \%$ & $11.68 \%$ & $5.94 \%$ & $5.15 \%$ & - & $25.94 \%$ \\
\hline Help in eating, feeding & $32.48 \%$ & $11.09 \%$ & $9.11 \%$ & $6.34 \%$ & $9.31 \%$ & $0.79 \%$ & $30.89 \%$ \\
\hline $\begin{array}{l}\text { Help in moving around the } \\
\text { surroundings }\end{array}$ & $25.94 \%$ & $14.85 \%$ & $11.29 \%$ & $6.73 \%$ & $6.14 \%$ & $0.79 \%$ & $34.26 \%$ \\
\hline Therapeutic sessions & $23.56 \%$ & $13.66 \%$ & $6.93 \%$ & $5.74 \%$ & $6.73 \%$ & $1.19 \%$ & $42.18 \%$ \\
\hline $\begin{array}{l}\text { Help in communication } \\
\text { with other people }\end{array}$ & $23.17 \%$ & $15.25 \%$ & $11.88 \%$ & $5.94 \%$ & $5.94 \%$ & $1.39 \%$ & $36.44 \%$ \\
\hline $\begin{array}{l}\text { Psychological support to } \\
\text { the family }\end{array}$ & $17.62 \%$ & $15.05 \%$ & $11.68 \%$ & $7.72 \%$ & $7.92 \%$ & $2.57 \%$ & $37.43 \%$ \\
\hline $\begin{array}{l}\text { Massage, rehabilitation } \\
\text { procedures }\end{array}$ & $15.64 \%$ & $11.09 \%$ & $12.08 \%$ & $7.52 \%$ & $12.67 \%$ & $0.99 \%$ & $40.00 \%$ \\
\hline \begin{tabular}{l} 
Minor repairs \\
\hline Insulin administration
\end{tabular} & $14.06 \%$ & $5.74 \%$ & $15.25 \%$ & $13.07 \%$ & $10.30 \%$ & $1.58 \%$ & $40.00 \%$ \\
\hline Help in animal care & $10.69 \%$ & $5.17 \%$ & $6.53 \%$ & $6.34 \%$ & $20.40 \%$ & $1.39 \%$ & $48.71 \%$ \\
\hline
\end{tabular}

Moreover, it may be perceived that the main factor determining the type of the provided services is the objective situation of the charges, particularly their age and health condition. The carers have most frequently referred to the interdependence between the type of services and the specific needs of the beneficiaries $(78 \%)$, as a consequence of the beneficiaries age, health condition and life position. Secondly, although the frequency was much smaller $(45 \%)$, the financial standing of the charges was referred to. The factors which are not related to the objective needs or the financial standing of the beneficiaries, including the request of the beneficiary or factors on the part of the PCK, were indicated much less frequently, by the maximum of $1 / 3$ of the carers.

The analysis of the research materials regarding the year 2018 reflects the specific reasons of the demand for the PCK care services. One of the basic reasons is the old age of the beneficiary $(74 \%)$, then physical disability $(11 \%)$, somatic disease $(6 \%)$, loneliness $(5 \%)$, mental disease $(3 \%)$, mental disability and other $(0.82 \%)$.

Also the issue of the quality and level of satisfaction from the performed care services at the homes of the ill was referred to. As presented in Chart 1, nearly all of the beneficiaries consider the quality of the provided services to be good, including $61 \%$ considering them to be very good. Only $3 \%$ of respondents were unable to clearly determine the quality level. None of the beneficiaries signalled a bad quality of the service. 


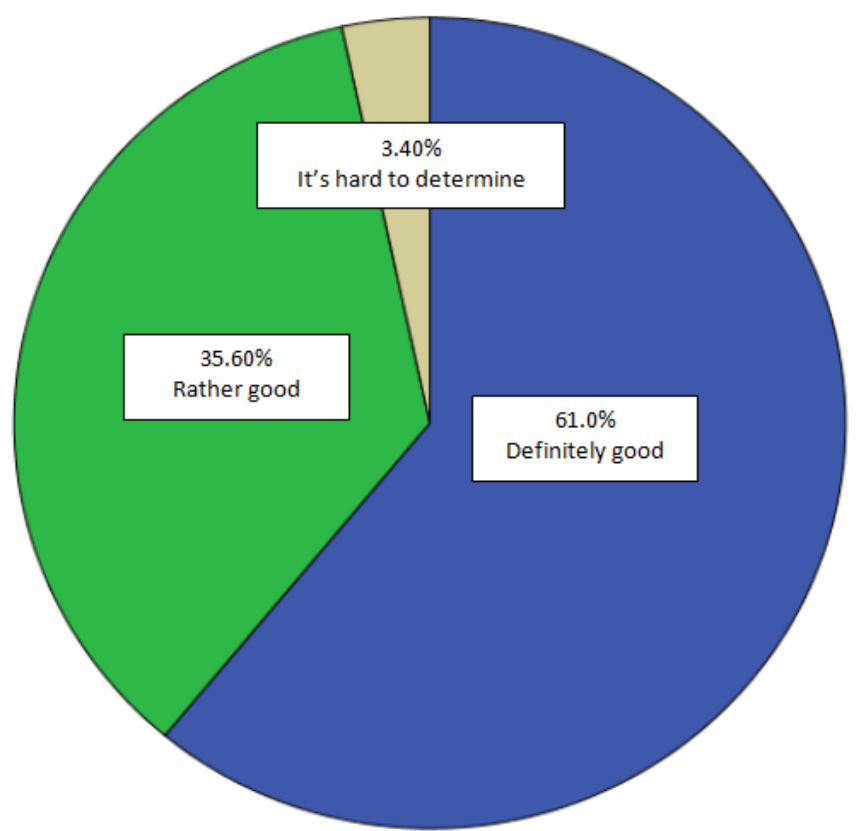

Chart 1. Opinions of the beneficiaries on the quality of the services offered by PCK

\section{Discussion and Conclusions}

Surely one of the most important tasks faced by the state and institutions is to create and provide adequate social services to the seniors in reply to the diagnosed social problem in that group, particular as regards illnesses, which force the provision of care and support.

For many years it has been emphasised within the ageing societies issue that there is a need to develop not only institutional care but mainly community care for the elderly. As it appears from the previous experience, community care is the cheapest to provide and ensures better integration of the elderly with their local communities. The demographic situation in Poland is similar to that of the other European countries, so it may be expected that the number of old people will grow gradually.

The demographic changes force a change of the old-age thresholds by extending the productive age, which results in increasing the retirement age. A major issue, both in Poland and in the other European countries, is to find such system solutions which would guarantee the elderly population their proper place within the society and to create conditions for decent life in a safe and friendly environment (Szarota 2004). It must be remembered that with regard to the extended process of the European societies ageing, the seniors are going to require attention and care more and more often, not only from families. Due to demographic reasons related to the progressing change of proportions between generations, families will not always be capable to provide support (Grewiński 2009). As regards social policy and support actions, we should focus on larger investments in the development of institutional forms of support to the seniors.

In the light of the presented research results and problem analysis based on the PCK 
report for 2018, the proposed offer of care services clearly indicates that the basic recipients of the services are the elderly, who are mostly satisfied with the level of the care services. The research results show the differentiation of the tasks performed by the PCK carers to their chargers.

Bearing in mind the changes which have occurred in the recent years as regard the family model, the number of children per family and long-term migration, considered shall be the situation of the care services market, where the demand for NGO provided services is going to grow. The social consequences of population ageing may be considered at various levels of the social life - the micro level formed by families, the mezo level of local communities, and the macro level of the whole society. It must be remembered that old people are a specific group of varied needs, aspirations, as well as health and social problems.

The provision and efficiency of actions, both the institutional ones and community care provided to the elderly, may be ensured providing that a series of assumptions are fulfilled:

1. The modern demographic trends, and particularly changes within the family structure and ageing processes, reflect that a major part of family care is replaced with various institutional solutions.

2. Due to the different areas of an old person activeness, support should be based on a specific type of service, adjusted both to the intellectual and the physical level of the senior.

3. Attention needs to be paid to the specifics of the ageing process, in consideration of the particular old-age phases, for which the hierarchy of needs, abilities and interest of the elderly change.

4. The perspective of locating an old person in a social environment - their functioning in the local community, the cultural aspects, family relations, neighbour relations, etc.

The growth in the number of old people contributes to a larger population of the ill, lonely, and disabled, who need support and care from the medical, rehabilitation as well as care and nursing point of view.

\section{References}

Auleytner J., Głębicka K. (2000). Polityka społeczna pomiędzy opiekuńczością a pomocniczością. Balets P.B. (1987). Theroretical Propositions of Life -span Developemental Psychology: On the Dynamics between Growth and Decline. Developemental Psychology No 23, s.15-29.

Auleytner J., Głąbicka K. (2001). Polskie kwestie socjalne na przełomie wieków.

Erikson E.H. (1998).The Life Cycle Completed .

Grewiński M. (2009). Usługi społeczne i socjalne jako wspólny obszar polityki i ekonomii społecznej.

Ekonomia społeczna No 3, 24-29.

Havighurst R.J.,Albrecht R. (1953). Older people.

Mielczarek A.( 2010). Człowiek stary w domu pomocy społecznej.

Rynkowska D., Błaszczuk K. (2016). Problemy społeczne i opiekuńcze seniorów i ich rodzin. Studium socjologiczne na przykładzie opinii pracowników socjalnych.

Synak B. (2002). Polska starość.

Szatur-Jaworska B.(2000). Ludzie starzy i starość w polityce społecznej.

Szatur-Jaworska B., Błędowski P., Dzięgielewska M. (2006). Podstawy gerontologii społecznej.

Szarota Z.(2004). Gerontologia społeczna i oświatowa. 